\title{
Autonomia nauczyciela w reformowanej szkole
}

\section{Charakter reform edukacyjnych w Polsce}

Zmiana ustroju polityczno-społecznego w Polsce w roku 1989 zapoczątkowała reformy edukacyjne. Po latach totalitaryzmu, w wolnym kraju oczekiwano uspołecznienia szkoły, samorządnego funkcjonowania wszystkich jej podmiotów ${ }^{1}$. Ważnym dokumentem, stała się ustawa z roku 1991, w której zawarto szereg zapisów sprzyjających decentralizacji i demokratyzacji oświaty. Przyznano nauczycielom, uczniom i rodzicom większą autonomię. Nauczyciele mogli decydować o programach nauczania, metodach kształcenia i środkach dydaktycznych. Uczniowie i rodzice uzyskali prawo do reprezentowania swoich interesów w adekwatnych instytucjach tj. samorząd uczniowski, rada rodziców i rada szkoły. Decentralizacja umożliwiała powstawanie szkół niepaństwowych, wdrażanie innowacji, prowadzenie eksperymentów pedagogicznych.

W 1999 podjęto kompleksową reformę, wprowadzono zmiany ustroju szkolnego, inne niż dotychczas zasady zarządzania i finansowania oświaty, radykalną reformę programów i metod pracy

$\overline{1}$ A. Popławska, Idea samorządności. Podmiotowość - autonomia - pluralizm, Wydawnictwo Trans Humana, Białystok 2001. 
dydaktyczno-wychowawczej, czterostopniowy awans zawodowy nauczycieli, a jako jej główny cel wskazano: „podniesienie poziomu edukacji społeczeństwa przez upowszechnienie wykształcenia średniego i wyższego, wyrównanie szans edukacyjnych, sprzyjanie poprawie jakości edukacji, rozumianej jako integralny proces wychowania i kształcenia"2.

System oświatowy z dwuszczeblowego przekształcono w trójszczeblowy - wprowadzono sześcioletnią szkołę podstawową, trzyletnie gimnazjum, trzyletnie licea i dwuletnie szkoły zawodowe. Informacji o osiągnięciach uczniów dostarczał system sprawdzianów i egzaminów zewnętrznych. Walorem oceniania $\mathrm{z}$ wykorzystaniem testów przygotowywanych przez Centralną Komisję Egzaminacyjną była obiektywizacja ewaluacji i możliwość porównywania wyników. Wprowadzono pluralizm programowy, zaproponowano nauczycielom dokonywanie wyboru spośród kilku ofert programów i podręczników szkolnych, ale też opracowanie programów autorskich lub modyfikacje programów. Obowiązywały tzw. podstawy programowe i standardy wymagań, które miały zagwarantować uczniom posiadanie odpowiedniego zakresu wiedzy i umiejętności. Dążono do urzeczywistnienia w szkole idei nauczania zintegrowanego i blokowego, aby dostosować kształcenie do potrzeb i możliwości rozwojowych dzieci oraz by uczniowie poznawali świat jako całość.

Kolejna reforma - w roku 2009 - była reformą programową, związaną niejako z obniżeniem wieku rozpoczęcia nauki w szkole podstawowej. We wrześniu 2009 roku w I klasach obok siedmiolatków pojawiły się dzieci sześcioletnie, których rodzice zadecydowali, że rozpoczną naukę szkolną. Wprowadzono też zmiany w organizacji kształcenia zawodowego.

Zaproponowana nowa podstawa programowa określała czego ma się nauczyć uczeń o przeciętnych uzdolnieniach z poszczególnych przedmiotów na każdym etapie edukacyjnym. Zdefiniowano zakres treści nauczania przedmiotów na kolejnych etapach edukacyjnych; treści przedstawiono w formie koniecznych do uzyskania efektów kształcenia. Skutkowało to zmianą programów nauczania i podręczników.

2 Reforma systemu edukacji. Projekt, WSiP, Warszawa 1998, s. 10. 
Ministerstwo ${ }^{3}$ zrezygnowało z zatwierdzania programów nauczania i zachęcało nauczycieli do opracowywania własnych programów, które mogły być zatwierdzane do użytku przez dyrektora danej szkoły po zasięgnięciu opinii rady pedagogicznej. W praktyce nauczyciele uzyskali możliwość opracowania samodzielnie lub we współpracy z innymi nauczycielami programu nauczania lub zaproponowania programu wybranego autora.

W roku 2017 podjęto bardziej kompleksową reformę o charakterze strukturalnym i programowym. Rozpoczęto likwidację gimnazjów, zaproponowano powrót do ośmioletniej szkoły podstawowej i czteroletniego liceum ogólnokształcącego oraz pięcioletniego technikum, a także powstanie szkół branżowych (zamiast zawodowych). Koniecznym następstwem zmian ustroju szkolnego stała się reforma programowa. W podstawie programowej wskazano co uczeń powinien umieć z danego przedmiotu po danym etapie edukacyjnym, powrócono do spiralnego układu treści tj. uczniowie wiedzę zdobytą na II etapie edukacyjnym mogą powtarzać i rozszerzać w trakcie dalszego kształcenia w wybranym typie szkoły ponadpodstawowej. Nauczyciele są zobowiązani do realizacji treści zawartych w podstawie, a programy i podręczniki muszą być z nią zgodne. Nauczyciele decydują o tym z jakich programów nauczania będą korzystać uwzględniając specyfikę szkoły i możliwości swoich uczniów.

Na podstawie analizy prawa oświatowego można stwierdzić, że kolejne reformy edukacji stwarzały warunki do autonomii nauczyciela, zwłaszcza jeśli chodzi o kwestie dydaktyczne i tworzenie lub modyfikowanie programów nauczania.

Warto sobie zadać pytanie, czy nie były to tylko deklaratywne przywileje, pozorna autonomia nauczyciela, która de facto nie miała szans na urzeczywistnienie ze względu na tryb przeprowadzania reform, brak odpowiedniego przygotowania podmiotów edukacji do pełnego uczestniczeniawzmianie, atakżeograniczeniaspołeczno-ekonomiczne oraz trudne do przewidzenia i niedające się kontrolować skutki reformatorskich działań. Interesujące diagnozy dotyczące efektów reform

$3 \quad$ Rozporządzenie Ministra Edukacji Narodowej z dnia 8 czerwca 2009 r. w sprawie dopuszczania do użytku w szkole programów wychowania przedszkolnego i programów nauczania oraz dopuszczania do użytku szkolnego podręczników, Dz.U. 2009, nr 89 poz. 730. 
edukacyjnych można znaleźć m.in. w pracach Kazimierza Denka, Jerzego Niemca, Bogusława Śliwerskiego, Mirosława Szymańskiego ${ }^{4}$.

\section{Autonomia - ustalenia terminologiczne}

Termin autonomia $\mathrm{w}$ naukach społecznych funkcjonuje w kilku różnych znaczeniach, uznaje się ją za prawo przysługujące jednostce oraz jej potrzebę, a także za cechę osoby - jej myślenia i działania.

W ujęciu filozoficznym autonomia to zdolność jednostki do samostanowienia lub samorządności. Wyróżnia się autonomię osobistą, moralną i polityczną. Autonomię osobistą, należy rozumieć jako możliwość niezależnego decydowania o samym sobie, realizację własnych dążeń, posiadanie kierunku działania w swoim życiư ${ }^{5}$ Autonomię osobistą odróżnia od kantowskiej autonomii moralnej neutralność metafizyczna. Autonomia polityczna jest właściwością poszanowania i uwzględniania w swoich decyzjach kontekstu politycznego ${ }^{6}$.

W psychologicznej teorii autodeterminacji opracowanej przez Richarda Ryana i Edwarda Deciego, autonomia wskazywana jest jako jedna $\mathrm{z}$ trzech podstawowych (obok kompetencji i przynależności), wrodzonych i uniwersalnych ludzkich potrzeb, których spełnienie pozwala na osiągnięcie dobrostanu? Potrzeba autonomii wiąże się

$4 \quad$ K. Denek, Toczaca się reforma edukacji, [w:] A. Karpińska (red.), Tocząca się reforma edukacji $w$ dialogu $i$ perspektywie, Wydawnictwo Trans Humana, Białystok 2008; J. Niemiec, Opinia o reformie oświaty, [w:] Cz. Kupisiewicz, M. Kupisiewicz, R. Nowakowska-Siuta (red.), Drogi i bezdroża polskiej oświaty w latach 1945-2005, Dom Wydawniczy Elipsa, Warszawa 2005; J. Niemiec, Edukacja „toczacych się" reform, [w:] A. Karpińska (red.), Edukacja w dialogu i reformie, Wydawnictwo Trans Humana, Białystok 2002; B. Śliwerski, Diagnoza uspołecznienia publicznego szkolnictwa III RP w gorsecie centralizmu, Oficyna Wydawnicza „Impuls”, Kraków 2013; M.J. Szymański, W poszukiwaniu drogi: szanse i problemy edukacji w Polsce, Wydawnictwo Naukowe Akademii Pedagogicznej, Kraków 2008; Idem, Szkoła - między tradycją, dążeniem do nowoczesności i chaosem, [w:] M.J. Szymański, B. Walasek-Jarosz, Z. Zbróg (red.), Zrozumieć szkołę. Konteksty zmiany, Wydawnictwo Akademii Pedagogiki Specjalnej, Warszawa 2016.

5 J. Dryden, Internet Encyclopedia of Philosophy. A Peer-Reviewed Academic Resource, http://www.iep.utm.edu/autonomy/ (dostęp: 09.09.2019).

6 Ibidem.

7 R.M. Ryan, E.L. Deci, Self-Determination Theory and the Facilitation of Intrinsic Motivation, Social Development, and Well-Being, "American Psychologist” 2000, t. 55, nr 1. s. 66-78. 
z ludzkim pragnieniem bycia sprawcą zdarzeń, podejmowaniem działań w zgodzie ze swoim systemem wartości i zainteresowaniami oraz zaaprobowania swojego działania na drodze autorefleksji ${ }^{8}$.

W Słowniku pedagogicznym autonomię zdefiniowano jako „samodzielność, niezależność, możliwość samostanowienia".

Autonomia, zdaniem Kazimierza Sośnickiego, wyraża się tym, że osoba sprawuje kontrolę nad własnymi działaniami i postawami, nad własnym rozwojem i doskonaleniem się. Wymaga od osoby umiejętności poznania samej siebie oraz kierowania sobą, swoimi myślami, uczuciami, wolą i czynami ${ }^{10}$. W definicji Sośnickiego autonomia zostaje powiązana nie tylko z samostanowieniem, ale także z samopoznaniem, samorozwojem i samodoskonaleniem się, jednak nie chodzi tutaj o egoistyczną troskę o siebie, ale o kompetencje sprawcze podmiotu i dążenie do trwałości charakteru, u podłoża której znajduje się świadomie podjęta decyzja działania, motywowana zasadami moralnymi i związanymi z nimi wartościami.

Weronika Wilczyńska zwraca uwagę, że autonomia „implikuje osobistą swobodę, niezależność, ale i odpowiedzialność za własne wybory i działania" ${ }^{11}$, wyraża się w rzeczywistej zdolności osoby do samodzielnego kierowania poszczególnymi aspektami swojego życia.

Warto też wspomnieć o relacyjnym ujęciu autonomii, w myśl którego kluczowe znaczenie dla funkcjonowania podmiotu mają relacje interpersonalne. Stają się one głównym źródłem poczucia tożsamości i zdolności niezbędnych do autonomicznego funkcjonowania ${ }^{12}$.

8 E.L. Deci, M. Vansteenkiste, Self-determination theory and basic need satisfaction: Understanding human development in positive psychology, „Ricerche di Psichologia” 2004, nr 27, s. 17-34.

9 Cz. Kupisiewicz, M, Kupisiewicz, Słownik pedagogiczny, PWN, Warszawa 2009, s. 15.

10 K. Sośnicki, Teoria środków wychowania, Warszawa 1973, cyt. za B. Śliwerski, hasło: Autonomia, [w:] K. Chałas, A. Maj (red.), Encyklopedia aksjologii pedagogicznej, Polskie Wydawnictwo Encyklopedyczne, Radom 2016, s. 127.

11 W. Wilczyńska, Analiza transakcyjna a rozwijanie autonomii w komunikacji szkolnej i obcojezycznej, [w:] M. Pawlak (red.), Autonomia w nauce jezzyka obcego - co osiagnęliśmy i dokąd zmierzamy, Wydział Pedagogiczno-Artystyczny UAM w Kaliszu, Uniwersytet Adama Mickiewicza w Poznaniu, Poznań - Kalisz - Konin 2008, s. 77.

12 T.L. Beauchamp, J.F. Childress, Principles of Biomedical Ethics, Sixth Edition, Oxford University Press, New York 2009, s. 103. 
Podobne stanowisko zajmuje Krzysztof Polak ${ }^{13}$, który podkreśla, że autonomię można interpretować wyłącznie jako rodzaj stosunków łączących człowieka z innymi ludźmi; stosunków wynikających z wzajemnego uzależnienia społecznego. Jest to szczególny typ relacji, gdzie występuje dwupodmiotowość, nauczyciel i uczeń, jako dwie subiektywności, dysponują własnymi wyobrażeniami o sobie, o swoich możliwościach i aspiracjach. Symetryczność tej relacji opiera się zarówno na wzajemnej komunikacji, spostrzeganiu, jak też wyodrębnianiu drugiej osoby z szerokiego pola własnego doświadczenia świata, na koncentracji na niej i podjęciu aktywności ze względu na nią. Oba podmioty we właściwy sposób komunikują drugiej stronie gotowość „świadczenia”, czyniąc to w pełni świadomie i dobrowolnie. Symetria oznacza też nastawienie obu partnerów nie tylko na przekazywanie własnych oczekiwań, opinii, przekonań, lecz przede wszystkim na wolę „uczenia się” drugiej osoby, na poznawanie jej wartości, dążeń i motywów, na ich poszanowanie i podejmowanie - w oparciu o to - aktywności wyrażającej życzliwość i akceptację.

Edukacja zorientowana podmiotowo zyskuje akceptację wielu pedagogów, którzy zwracają uwagę na zależność między autonomią nauczycieli i osób uczących się. Niewątpliwie autonomię ucznia w obszarze szkoły warunkuje autonomia nauczyciela i jego kompetencje, które pozwalają na właściwe organizowanie procesu kształcenia i realizację idei podmiotowości w szkole. Urzeczywistnienie tej idei będzie możliwe wówczas, gdy osoby ucznia i nauczyciela połączy symetryczna relacja - interakcja dwupodmiotowa oparta na dialogu, gdy nastąpi autentyczne „spotkanie osób”. Nauczyciel będzie nie tylko „nadawcą”, ale pozostanie otwarty na sygnały płynące od ucznia i dokona ich interpretacji, dzięki czemu uczestnicy interakcji nawzajem wytyczą drogi swojego postępowania ${ }^{14}$.

Przyjmując jeszcze inną optykę - autonomię można również uznać za warunek profesjonalnego wykonywania ważnych społecznie zawodów tj. lekarz, prawnik, a także nauczyciel. Zdaniem

13 K. Polak, Edukacja integralna a idea podmiotowości człowieka w procesach kształcenia $i$ wychowania, [w:] J. Kędzierska, K. Polak (red.), Nauczanie zintegrowane w szkole, Wydawnictwo Państwowej Wyższej Szkoły Zawodowej w Krośnie, Krosno 2002.

14 A. Popławska, $W$ drodze ku pełnej podmiotowości. Kompetencje podmiotowe gimnazjalistów, Wydawnictwo NWSP, Białystok 2013, s. 81. 
B. Maxwella ${ }^{15}$ umożliwienie profesjonalistom autonomii zawodowej jest najskuteczniejszym sposobem na maksymalizację jakości ich usług.

Joanna Madalińska-Michalak analizując kwestię profesjonalizmu w zawodzie nauczyciela dochodzi do wniosku, że jego wyróżnikiem jest autonomia nauczycieli, powiązana z wzmacnianą oddolnie odpowiedzialnością za proces kształcenia i wychowania w szkole ${ }^{16}$.

\section{Autonomia nauczyciela i jej znaczenie}

Przez autonomię nauczyciela - Bogusław Śliwerski - rozumie jego samoistne myślenie oraz samodzielnie podejmowane działania pedagogiczne i (auto)edukacyjne pod jednym wszakże warunkiem, że nie naruszają one stanu wolności jednostek pozostałych i są nastawione na kontynuację własnej istoty oraz tożsamości osób w zasięgu jego wpływów ${ }^{17}$.

Antoni Smołalski w 1987 roku oczekując na demokratyzację szkoły, charakteryzował to jak powinna funkcjonować samorządna szkoła i autonomiczny nauczyciel. Perspektywę tę opisał następująco:

nauczyciel traktowany byłby podmiotowo, miałby prawo do opracowania programów nauczania (...), prawo opracowywania podręczników szkolnych, oraz realizowania ich w swojej szkole, (...), prawo do innej niż standardowa organizacji pracy w szkole; prawo uzyskiwania porad zawodowych ze strony władz szkolnych i aparatu doskonalenia, gdy będzie taka potrzeba ${ }^{18}$.

Podobne stanowisko, w kwestii autonomii nauczycieli, zajmuje Julian Radziewicz - wskazując, że może ona wyrażać się tym, że nauczyciele mają prawo (i korzystają z niego) do podejmowania

15 B. Maxwell, To what extent do teachers have professional autonomy?, https://www. academia.edu/12891872/To_what_extent_do_teachers_have_professional_autonomy (dostęp: 09.09.2019).

16 J.M. Michalak, Profesjonalizm w zawodzie nauczyciela, [w:] J.M. Michalak (red.), Etyka i profesjonalizm w zawodzie nauczyciela, Wydawnictwo Uniwersytetu Łódzkiego, Łódź 2010, s. 116.

17 B. Śliwerski, Lęk wobec nauczycielskiej wolności, [w:] W. Prokopiuk (red.), Rozwój nauczyciela w okresie transformacji, Wydawnictwo Trans Humana, 1998, s. 112.

18 A. Smołalski, Koncepcja szkoły samorządnej i samoregulującej się, „Edukacja” 1987, nr 1, s. 8. 
samodzielnych - w szczególności innowacyjnych decyzji wychowawczych; samodzielnie planuja, organizują, kontrolują i oceniają codzienną pracę $\mathrm{z}$ wychowankami. Wyjaśnia dalej, że o podejmowaniu decyzji innowacyjnych możemy mówić wówczas, gdy nauczyciel decyduje się na wprowadzenie do swojej pracy elementu nowego jeszcze niewypróbowanego i stwarzającego uzasadnioną nadzieję, że będzie on stanowił optymalne rozwiązanie jakiegoś problemu praktycznego. Rzeczywiste prawo nauczycieli do podejmowania innowacyjnych decyzji wychowawczych może świadczyć o autonomii nauczycieli w danej szkole - wówczas i przede wszystkim wtedy, gdy wyraża się ona w realizowanym prawie do oceny i zmieniania systemu wychowawczego według własnej wewnątrzszkolnie opracowanej i przyjętej przez zespół nauczycielski, uczniowski i rodzicielski - koncepcji pedagogicznej ${ }^{19}$.

Jerzy Niemiec zwraca uwagę na istotne aspekty rozpatrywania autonomii pedagoga. Pierwszy łączy się z oczywistym faktem wielości nowych informacji, nowych umiejętności i rozwoju nowoczesnej technologii. Dlatego nauczyciel nie może czekać na sygnał czy przyzwolenie „z góry” lub „z zewnątrz”, sam powinien stawać się decydentem. Może jest to najważniejsza przemiana zawodu pedagoga polegająca na przewartościowaniu go $\mathrm{z}$ osoby wypatrującej instrukcji, na profesjonalistę kreującego decyzje samodzielne.

Autor podkreśla, że formułą najprostszą może stać się przekonanie, że autonomia to prawo nauczyciela do eliminacji niektórych treści pedagogicznej działalności, prawo do adaptacji nowych treści tych działań oraz jednocześnie naturalna dążność do reinterpretacji wszystkiego, co temu procesowi podlegać powinno. Reinterpretacja według najnowszych osiągnięć nauki, według własnych przekonań i uznawanego systemu wartości. Walorem praktycznej realizacji tych uprawnień pedagoga stawać się powinien dialog, poszukiwanie płaszczyzny porozumienia, a także zasady twórczej, wzajemnej i partnerskiej działalności. Takie strategie postępowania prowadzą do szerokiego uwzględniania pozostałych partnerów edukacyjnych poczynań, a zatem do interautonomii ${ }^{20}$.

19 J. Radziewicz, Szkoła demokracji-demokracja w szkole, [w:] J. Radziewicz (red.), Nauka demokracji, CODN, Warszawa 1993, s. 1-2.

20 J. Niemiec, Nauczyciele w przemianie i perspektywie, [w:] W. Prokopiuk (red.), Rozwój nauczyciela w okresie transformacji, Wydawnictwo Trans Humana, Białystok 1998, s. 80. 
W przypadku nauczyciela bycie autonomicznym podmiotem jest świadomą formą niezależnego nauczycielstwa, wyzwolonego z przepisów zewnętrznie narzuconej roli, nauczycielstwa indywidualnej odpowiedzialności, utożsamiającego się ze swym działaniem, biorącego za nie odpowiedzialność ${ }^{21}$. Tak więc przeniesienie odpowiedzialności z instytucji na osobę nauczyciela, wiąże się ze zmianą stylu działania nauczyciela.

Kazimierz Denek w swoich pracach wiąże autonomię nauczyciela z jego samowiedzą pedagogiczną oraz kompetencjami. Mianem nauczycieli podmiotowych określa tych, którzy wykazują samodzielność i swobodę w doborze celów, treści, metod, form organizacyjnych i środków dydaktycznych. Wskazuje, że brak autonomii prowadzi do zmniejszenia odpowiedzialności za wyniki pracy dydaktyczno-wychowawczej i ogranicza kreatywność nauczycieli ${ }^{22}$.

Dokonawszy przeglądu literatury polskiej i światowej - Joanna Madalińska-Michalak stwierdza:

coraz częściej w rozważaniach nad profesjonalizmem nauczyciela jako jego wyróżnik wskazuje się zatem na autonomię nauczycieli przejawiająca się w możliwościach realnego wpływu na kierunki działań i procesy zachodzące w ich środowisku pracy. Nauczyciele mogą pretendować do profesjonalizmu przez zaangażowanie się $\mathrm{w}$ ustanawianie $\mathrm{i}$ wypracowanie dobrych relacji z uczniami, rodzicami, z kolegami z pracy, ze społecznością lokalną oraz z tymi wszystkimi, którzy znajdują się niejako poza profesjonalnymi ramami tego zawodu ${ }^{23}$.

Autonomia nauczyciela wyraża się zatem we współdecydowaniu o realizowanych treściach kształcenia, świadomym, samodzielnym wyborze strategii nauczania, odpowiednim projektowaniu zajęć, pełnym zaangażowania, relacyjnym, twórczym/innowacyjnym, odpowiedzialnym i refleksyjnym realizowaniu procesu dydaktyczno-wychowawczego. Stałe czynienie refleksji nad własnym działaniem sprzyja poprawie jego efektywności i pozwala na optymalne wykorzystanie osobistego potencjału nauczyciela w sytuacji ciągłej zmiany.

Jak już wcześniej podkreślono, autonomia nauczyciela ma różne aspekty, można powiązać ją z funkcjonowaniem w sferze osobistej

21 H. Kwiatkowska, Edukacja nauczycieli. Konteksty - kategorie - praktyki, Instytut Badań Edukacyjnych, Warszawa 1997, s. 75.

22 K. Denek, Ku dobrej edukacji, Wydawnictwo Akapit, Toruń - Leszno 2005, s. 80.

23 J.M. Michalak, Profesjonalizm w zawodzie nauczyciela..., s. 115. 
i z pełnieniem roli zawodowej. Jeśli uwzględnimy wymiar edukacyjny będzie związana $\mathrm{z}$ zaangażowaniem $\mathrm{w}$ proces zmian, tworzeniem środowiska edukacyjnego zaspokajającego różne potrzeby dzieci, warunkiem niezbędnym do podjęcia indywidualizacji nauczania, pozwalającym na adekwatny dobór treści, metod, form, środków dydaktycznych i sprzyjającym wprowadzaniu innowacji.

W wymiarze osobowym autonomia umożliwia rozwój osobisty, sprzyja doskonaleniu zawodowemu, zapewnia poczucie podmiotowego funkcjonowania, wymaga krytycznej refleksji i kreatywności, pozwala na dialog i współdziałanie oraz stanowi element motywacji.

Maria Wysocka zwraca uwagę na szereg czynników ograniczających autonomię nauczyciela. Są to m.in. przekonania i postawy nauczycieli, przyjmowane przez nauczycieli strategie przetrwania, przepisy i ustalenia władz ${ }^{24}$. Ukształtowane w toku studiów i pracy zawodowej postawy nauczycieli mogą ograniczać poszukiwanie autonomicznych rozwiązań, ponieważ postępowania standardowe są pewniejsze i bezpieczniejsze. Podobnie utrudniać autonomiczne funkcjonowanie będą nauczycielskie strategie przetrwania. W strategii terapii zajęciowej nauczyciel skupia się tylko na dostarczeniu uczniom pracy i nie poszukuje nowych rozwiązań. Strategia rutyny, czyli stosowanie ciągle tych samych rozwiązań, strategia wycofania się, czyli niereagowanie na to, co się dzieje w klasie pozwalają nauczycielowi spokojnie przebyć zajęcia ${ }^{25}$.

Joanna Michalak wypowiadając się w kwestii uwarunkowań autonomii nauczycieli podkreśla, że jest ona „zawsze ograniczana w pewien sposób przez regulacje rządowe, regulacje odnoszące się do pracy nauczyciela, przez regulacje administratorów oświaty. Autonomia i odpowiedzialność nauczyciela zmienia się często wraz z upływem czasu"26.

W prowadzonych przez Eurydice badaniach nad autonomią nauczycieli w Europie ${ }^{27}$ poszukiwano odpowiedzi na pytanie czy zmiany

24 M. Wysocka, Granice autonomii nauczyciela języków obcych i jego uczniów, [w:] M. Pawlak (red.), Autonomia w nauce języka obcego - co osiągnęliśmy $i$ dokąd zmierzamy, Wydział Pedagogiczno-Artystyczny UAM w Kaliszu, Uniwersytet Adama Mickiewicza w Poznaniu, Poznań - Kalisz - Konin 2008, s. 16-17. Ibidem.

26 J.M. Michalak, Profesjonalizm w zawodzie nauczyciela..., s. 109.

27 Levels of Autonomy and Responsibilities of Teachers in Europe, przekł. E. Kolanowska, Agencja Wykonawcza ds. Edukacji, Kultury i Sektora Audiowizualnego/Fundacja Rozwoju Systemu Edukacji, Warszawa 2009. 
dokonujące się w krajach europejskich w zakresie obowiązków powierzanych nauczycielom doprowadziły do rozszerzenia autonomii i zadań dydaktyczno-wychowawczych. Raport z badań pokazuje, że

nowe obowiązki i zadania, osadzające nauczycieli w nowej roli, pojawiły się obok tradycyjnych atrybutów związanych z tym zawodem (...). Poza ścianami klasy i codzienną interakcją z uczniami nauczyciele są coraz częściej zobowiązani do udziału w różnych pracach, jakie organizuje się w szkołach. W coraz większym stopniu wymaga się też od nich aktywnego zaangażowania w sprawy wykraczające poza szkołę - udziału w tworzeniu reform edukacyjnych lub opracowywania innowacji dydaktycznych.

Oczywiście istotę zawodu nauczyciela nadal stanowią stałe podstawowe zadania związane z prowadzeniem lekcji w klasie - i w tej sferze nauczyciele mają bardzo szerokie obowiązki i autonomię. Na przykład w ogromnej większości krajów sami niemal w pełni odpowiadają za wybór metod nauczania. (...). Nauczyciele mają przeważnie jeszcze większą swobodę działania, jeśli chodzi o wybór materiałów dydaktycznych, a w szczególności podręczników. Poza krajami, które zwyczajowo zapewniały nauczycielom pełną swobodę w tym zakresie, m.in. Francji, Włoch i Szwecji, wzrasta liczba krajów, w których nauczyciele wybierają podręczniki z ustalonej listy. Kolejnym zadaniem stanowiącym istotę pracy dydaktycznej jest stałe wewnętrzne ocenianie uczniów. W większości krajów europejskich nauczyciele pozostają głównymi arbitrami w sprawach dotyczących oceny postępów uczniów w nauce. W większości przypadków odgrywają także bardzo istotną rolę w decyzjach, które zobowiązują uczniów do powtarzania klasy, jeśli nie osiągnęli poziomu warunkującego promocję do następnej klasy. (...) We wszystkich krajach europejskich rozwiązania, w ramach których szkolne programy nauczania były opracowywane na poziomie centralnym bez żadnego wkładu ze strony władz lokalnych lub szkół, zostały całkowicie zastąpione takimi, które przewidują kilkuetapowe prace nad treściami programu nauczania ze znacznym udziałem szkół i nauczycieli ${ }^{28}$.

Zwrócono jednocześnie uwagę że ,jeśli chodzi o szkolne plany nauczania, ocenianie oraz wybór metod nauczania i podręczników, rozrastanie się wewnętrznych mechanizmów koordynacji znacznie ogranicza w praktyce swobodę nauczycieli w sprawach dydaktycznych i wyznacza dyrektorom szkół nową rolę liderów"29.

Można stwierdzić, że zmiany dokonujące się w oświacie formalnie zwiększają autonomię nauczycieli w różnych obszarach ich funkcjonowania, mogą oni podejmować decyzje dotyczące programów nauczania, tworzyć programy autorskie, decydować o wyborze podręczników, metod, form, środków dydaktycznych, wprowadzać innowacje,

28 Ibidem, s. 69.

29 Ibidem, s. 72. 
współdecydować o planach nauczania i ocenianiu uczniów. Jednocześnie stosowanie ścisłego nadzoru i kontroli działań podejmowanych przez nauczycieli, zobligowanie ich do przestrzegania licznych procedur, biurokratyzacja, wprowadzenie standaryzowanych testów podczas sprawdzianów i egzaminów zewnętrznych sprzyja uniformizacji, jest sprzeczne $\mathrm{z}$ indywidualizacją kształcenia i uniemożliwia podmiotowe funkcjonowanie nauczycieli i uczniów w szkole.

Warto $\mathrm{w}$ tym miejscu ponowić pytanie czy w reformowanej szkole mamy do czynienia z urzeczywistnieniem czy pozorem autonomii?

\section{Autonomia nauczyciela w świetle wyników badań własnych}

Celem badań była diagnoza pracy zawodowej nauczycieli w aspekcie ich autonomicznego funkcjonowania oraz porównanie stanu rzeczy w trzech okresach badawczych: I etap to rok 1998, II etap - rok 2009, III etap - rok 2019. Lata te to czas, kiedy szkoła jest w trakcie reformy i jednocześnie w przededniu wprowadzenia kolejnych zmian.

Badaniem sondażowym $\mathrm{z}$ wykorzystaniem kwestionariusza ankiety objęto losowo wybranych nauczycieli województwa podlaskiego z dużego i małego miasta oraz ze wsi ze szkół podstawowych i ponadpodstawowych. W zdecydowanej większości były to kobiety (ponad $80 \%$ ) z dużym stażem pracy w szkole, $\mathrm{z}$ wykształceniem wyższym magisterskim. W roku 1998 było to 206 respondentów, w roku 2009 - 284 osób, w roku 2019 - 144 nauczycieli.

W trakcie badań dążono do ustalenia:

- Jak często nauczyciele decydują o istotnych elementach procesu kształcenia?

- Czy i jaka jest gotowość nauczycieli do podejmowania samodzielnych decyzji i ponoszenia odpowiedzialności za nie?

- Jak często nauczyciele podejmują czynności wymagające samodzielności myślenia i działania oraz aktywność innowacyjną?

Jak przedstawiono wcześniej $\mathrm{w}$ rozporządzeniach wydawanych w związku z kolejnymi reformami edukacji formalnie umożliwiano nauczycielom decydowanie o ważnych elementach procesu kształcenia. W badaniach interesowało nas jak często nauczyciele korzystają z przypisanych im uprawnień, czyli jak często podejmują decyzje lub współdecydują o programach nauczania, metodach kształcenia, środkach dydaktycznych, systemie kontroli i oceny uczniów. 
Na podstawie analizy uzyskanych wyników można stwierdzić, że we wszystkich etapach $(1998,2009,2019)$ większość nauczycieli - około $80 \%$ deklarowała wysoką częstotliwość decydowania o programie nauczania, w tym około połowa badanych wybierała kategorię zawsze. Ustalono, że to decydowanie przejawiało się zazwyczaj w dokonywaniu odpowiednich modyfikacji programu, natomiast bardzo rzadko opracowywano programy autorskie. Sytuacja taka może być warunkowana, z jednej strony, koniecznością uwzględnienia w każdym programie „podstaw programowych”, z drugiej, brakiem umiejętności niezbędnych do tworzenia i ewaluacji programu nauczania i obawą nauczycieli, że nie podołają temu zadaniu.

Następnym istotnym elementem procesu kształcenia są metody, czyli sposoby pracy nauczyciela z uczniami. Odpowiedni ich dobór i wykorzystanie umożliwia wielostronny rozwój ucznia. Zgromadzone dane upoważniają do stwierdzenia, że zdecydowana większość badanych (około 95\%) we wszystkich okresach $(1998,2009,2019)$ często podejmowała decyzje dotyczące sposobów pracy z uczniem na lekcji. Wobec tych deklaracji pozostaje mieć nadzieję, że nauczyciele dobierając je uwzględniali nie tylko cele, treści nauczania, ale też możliwości i potrzeby uczących się. To dzięki właściwie dobranym metodom uczeń może przejawić różnorodną aktywność; wymieniać doświadczenia z innymi; rozwiązywać zadania o charakterze teoretycznym i praktycznym; eksperymentować, rozwiązywać problemy; współdziałać nie tylko z nauczycielem, ale też $\mathrm{z}$ rówieśnikami. Badania prowadzone przez różne zespoły badawcze dowodzą, że nauczyciele dość rzadko korzystają z metod unowocześniających proces kształcenia, dających dużo satysfakcji i uczniowi i nauczycielowi ${ }^{30}$.

Lepszemu rozumieniu poznawanych treści i wyzwalaniu potencjału uczniów mogą też sprzyjać odpowiednio dobrane środki dydaktyczne. O podejmowanie decyzji w tej ważnej w nauczaniu kwestii zapytano badanych nauczycieli. Podobnie jak poprzednio zdecydowana większość respondentów we wszystkich okresach (1998, 2009, 2019) wybierała kategorie wysokiej częstotliwości, w tym ponad połowa kategorię

30 S. Dylak, Architektura wiedzy w szkole, Wydawnictwo Difin, Warszawa 2013; A. Popławska, $W$ drodze ku petnej podmiotowości...; Wykorzystanie eksperymentów i metod aktywizujacych w nauczaniu - problemy i wyzwania. Raport z badań, Centrum Nauki Kopernik, Warszawa 2009. 
zawsze. Wobec tych deklaracji pojawia się pytanie na ile nauczyciele "cyfrowi imigranci" dobierają je odpowiednio do potrzeb i oczekiwań "cyfrowych tubylców”, których tożsamość w dużej mierze kształtuje się w cyberprzestrzeni. Doniesienia z badań dotyczących TIK w pracy dydaktycznej, zawierają niepokojące wnioski, że niewielu nauczycieli w pełni w praktyce edukacyjnej wykorzystuje technologie cyfrowe ${ }^{31}$. Katarzyna Borawska-Kalbarczyk słusznie podkreśla, że specyficzne cechy funkcjonowania młodego pokolenia cyfrowych tubylców, winny „przyczynić się do redefinicji szkolnego środowiska uczenia się tak, aby odpowiadała ona na potrzeby, oczekiwania i możliwości uczenia się pokolenia Z"32.

Kolejną kwestią, o której wypowiadali się badani nauczyciele, było decydowanie o systemie kontroli i oceny. Można stwierdzić, że stanowisko reprezentowane przez ankietowanych nie różni się w kolejnych okresach badania $(1998,2009,2019)$ i zdecydowana większość deklaruje wysoką częstotliwość, jeśli chodzi o decydowanie o systemie kontroli i oceny. Szczegółowy rozkład głosów jest nieco inny niż poprzednio. Około jedna trzecia wybierała kategorię bardzo często i ponad $40 \%$ zawsze. Należy pamiętać, że w wielu szkołach funkcjonuje wewnątrzszkolny system oceniania i wszyscy nauczyciele współdecydują o jego kształcie oraz niekiedy ustalany jest przedmiotowy system oceniania.

Ważne i potrzebne jest autonomiczne funkcjonowanie nauczycieli w omawianym zakresie, jeśli chcą oni skutecznie eliminować niepowodzenia dydaktyczno-wychowawcze. Elastyczne działanie w przestrzeni kontroli i oceny uczniowskich osiągnięć, pozwala uwzględnić zmienność sytuacji, którym podlega uczeń, związanych z jego rozwojem i uwarunkowaniami społeczno-ekonomicznymi i chronić przed długotrwałym doświadczaniem porażki, które prowadziłoby do ich wykluczenia. Anna Karpińska opowiada się za traktowaniem niepowodzeń jako porażki wszystkich podmiotów edukacyjnych i wskazuje

$31 \quad$ Polska szkoła $w$ dobie cyfryzacji. Diagnoza 2017. Raport opracowany przez zespół badawczy Wydziału Pedagogicznego Uniwersytetu Warszawskiego oraz PCG Edukacja, Warszawa 2017. https://www.nck.pl/upload/attachments/319726/RAPORT\%20CYFRYZCJA \%20SZK\%C3\%93\%C5\%81\%202017.pdf (dostęp: 09.09.2019).

32 K. Borawska-Kalbarczyk, Kompetencje informacyjne uczniów w perspektywie zmian szkolnego środowiska uczenia się, Wydawnictwo Akademickie Żak, Warszawa 2015, s. 462. 
na determinowanie przez niepowodzenia biografii szkolnej, aspiracji edukacyjnych i życiowych uczniów ${ }^{33}$.

Sondowano także, jaka jest gotowość nauczycieli do samostanowienia i ponoszenia odpowiedzialności za podejmowane decyzje. Badani ustosunkowywali się do stwierdzeń świadczących o ich gotowości w tym względzie. Większość respondentów - około 70\% (w każdym okresie badawczym) konstatowała, że choć nauczyciel powinien decydować sam, to należy jednak konsultować te decyzje z władzami szkoły. Tylko nieliczni nauczyciele (około 4\%) przyznali słuszność tezie, że należy odwoływać swoje postępowanie do zaleceń władz szkoły. Stwierdzenie świadczące o tym, że nauczyciele są w pełni gotowi do stanowienia o sobie i swojej pracy oraz ponoszenia odpowiedzialności za swoje decyzje, wybrała około jedna trzecia (1998), ponad jedna piąta (2009) i ponad jedna czwarta (2019) badanych. Można więc powiedzieć, że tylko te grupy czuły się w pełni gotowe do autonomicznych poczynań, pozostali respondenci oczekują wsparcia lub nadzoru ze strony władz szkoły.

O tym, że nauczyciel jest jednostką niezależną świadczy z pewnością to, że ma on poczucie odpowiedzialności za swoje działanie przede wszystkim przed samym sobą. Zdecydowana większość badanych nauczycieli (80\%) stwierdziła, że czują się odpowiedzialni za swoją pracę przed sobą, ale też przed swoimi uczniami i przed dyrekcją szkoły. Wyraźnie uwidacznia się tutaj uwikłanie nauczycielskiej autonomii w konieczność dostosowania się do regulacji rządowych, samorządowych, administracji oświatowej i regulacji wewnątrzszkolnych.

Samodzielność myślenia i działania nauczycieli przejawia się w tym, iż nie wymagają oni ciągłego instruowania, często podejmują działania wykraczające poza to, co jest normalne, typowe oraz analizują swoją działalność i umieją dostrzec jej pozytywne i negatywne skutki. Dokonują samooceny swojej pracy i nie pozostają bierni wobec błędów, podejmują walkę ze zjawiskami negatywnymi. Analizując deklaracje badanych stwierdzono, że wraz z upływem czasu i przeprowadzania kolejnych reform większy odsetek nauczycieli częściej oczekuje na wskazówki nadzoru pedagogicznego, wysoką częstotliwość wskazywało w roku 1998 - 15\% badanych; w roku 2009 - 23\%,

33 A. Karpińska, Niepowodzenia edukacyjne - renesans myśli naukowej, Wydawnictwo Trans Humana, Białystok 2013. 
a w roku 2019 - 27\%, prawie dwa razy więcej niż w początkowym okresie reformowania szkoły. Natomiast we wszystkich etapach badania zbliżony, wysoki odsetek (odpowiednio 77\%, 66\%, 72\%) nauczycieli deklarował częste wykraczanie poza to, co typowe. Jednak nie przekłada się to na wprowadzanie do praktyki edukacyjnej innowacji pedagogicznych. Około jedna trzecia badanych w kolejnych okresach (1998 - 35\%, 2009 - 31\%, 2019 - 33\%) deklarowała wprowadzenie nowatorskich rozwiązań programowych i metodycznych służących poprawie jakości pracy nauczyciela i ucznia.

Nauczyciele postrzegają siebie jako osoby refleksyjne, prawie wszyscy badani we wskazanych okresach badawczych wybierali kategorie wysokiej częstotliwości, ustosunkowując się do twierdzenia „analizuję swoją pracę pod kątem jej efektywności".

\section{Podsumowanie}

Mimo wprowadzanych reform i związanych z nimi zmian dokonujących się w szkole odczucia nauczycieli odnoszące się do ich autonomicznego funkcjonowania w procesie dydaktycznym nie zmieniają się. Samoocena nauczycieli, wyrażona w badaniach, dotycząca niezależności zawodowej i podmiotowego sprawstwa jest wysoka. Nauczyciele są świadomi, że mają określone prawa i wyrażają przekonanie, że często podejmują autonomiczne decyzje przyjmując na siebie odpowiedzialność za przebieg procesu kształcenia. Uwikłani są jednocześnie w szereg zależności od regulacji wewnątrzszkolnych, samorządowych, rządowych i administracji oświatowej. Można przypuszczać, że są niejako rozdarci między wolnością a zależnością, między samostanowieniem a regulacjami zewnętrznymi, między potencjałem osobistym a wymogami nowoczesnej edukacji, między oczekiwaniami własnymi a zmieniającymi się oczekiwaniami społecznymi.

Raporty o stanie oświaty świadczą o tym, że obecne funkcjonowanie nauczycieli w zawodzie nie przekłada się w znaczący sposób na podniesienie poziomu jakości edukacji i trudno istniejący stan rzeczy uznać za zadowalający. Być może autonomia nauczycieli jest pozorna i warto prowadzić dalsze eksploracje w tym zakresie. Prawdziwie autonomiczny nauczyciel dba o rozwój własny, ciągle doskonali swoje umiejętności, znakomicie wypełnia swoją rolę zawodową, charakteryzuje go refleksyjność i odpowiedzialność za przebieg procesu 
dydaktyczno-wychowawczego. Autonomiczny nauczyciel umożliwia także autonomiczne funkcjonowanie uczniom, a to wszystko sprzyja edukacyjnej efektywności.

\begin{abstract}
The text presents the issue of autonomy. The centre of considerations is the conceptualization of the concept of "teacher autonomy" and the exemplification of the various dimensions of teacher autonomy during constant education reforms in Poland. The work consists of three parts. The first characterizes subsequent school reforms carried out in democratic Poland. Particular attention was paid to regulations contained in educational law related to teacher autonomy. The second part discusses the concept of „autonomy” and „teacher autonomy”. An attempt was made to identify the stimulators and inhibitors of teacher autonomy. The third part presents selected results of periodically conducted research on the professional work of teachers, in particular their autonomy.
\end{abstract}

\title{
Bibliografia
}

Beauchamp T.L., Childress J.F., Principles of Biomedical Ethics, Sixth Edition, Oxford University Press, New York 2009.

Borawska-Kalbarczyk K., Kompetencje informacyjne uczniów w perspektywie zmian szkolnego środowiska uczenia się, Wydawnictwo Akademickie Żak, Warszawa 2015.

Deci E.L., M. Vansteenkiste, Self-determination theory and basic need satisfaction: Understanding human development in positive psychology, „Ricerche di Psichologia” 2004, nr 27.

Denek K., Ku dobrej edukacji, Wydawnictwo Akapit, Toruń - Leszno 2005.

Denek K., Tocząca się reforma edukacji, [w:] A. Karpińska (red.), Tocząca się reforma edukacji $w$ dialogu i perspektywie, Wydawnictwo Trans Humana, Białystok 2008.

Dylak S., Architektura wiedzy w szkole, Wydawnictwo Difin, Warszawa 2013.

Karpińska A., Niepowodzenia edukacyjne - renesans myśli naukowej, Wydawnictwo Trans Humana, Białystok 2013.

Kupisiewicz Cz., Kupisiewicz M., Słownik pedagogiczny, PWN, Warszawa 2009.

Kwiatkowska H., Edukacja nauczycieli. Konteksty - kategorie - praktyki, Instytut Badań Edukacyjnych, Warszawa 1997. 
Levels of Autonomy and Responsibilities of Teachers in Europe tłum. E. Kolanowska, Zakres autonomii i odpowiedzialności nauczycieli $w$ Europie, Agencja Wykonawcza ds. Edukacji, Kultury i Sektora Audiowizualnego/Fundacja Rozwoju Systemu Edukacji, Warszawa 2009.

Michalak J.M., Profesjonalizm w zawodzie nauczyciela, [w:] J.M. Michalak (red.), Etyka i profesjonalizm w zawodzie nauczyciela, Wydawnictwo Uniwersytetu Łódzkiego, Łódź 2010.

Niemiec J., Edukacja „toczacych się" reform, [w:] A. Karpińska (red.), Edukacja w dialogu i reformie, Wydawnictwo Trans Humana, Białystok 2002.

Niemiec J., Nauczyciele $w$ przemianie i perspektywie, [w:] W. Prokopiuk (red.), Rozwój nauczyciela w okresie transformacji, Wydawnictwo Trans Humana, Białystok 1998.

Niemiec J., Opinia o reformie oświaty, [w:] Cz. Kupisiewicz, M. Kupisiewicz, R. Nowakowska-Siuta (red.), Drogi i bezdroża polskiej oświaty w latach 1945-2005, Dom Wydawniczy Elipsa, Warszawa 2005.

Paris S.G., Ayres L.R., Stawanie się refleksyjnym uczniem i nauczycielem, Wydawnictwo Szkolne i Pedagogiczne, Warszawa 1997.

Polak K., Edukacja integralna a idea podmiotowości człowieka w procesach kształcenia i wychowania, [w:] J. Kędzierska, K. Polak (red.), Nauczanie zintegrowane w szkole, Wydawnictwo Państwowej Wyższej Szkoły Zawodowej w Krośnie, Krosno 2002.

Popławska A., Idea samorządności. Podmiotowość - autonomia - pluralizm, Wydawnictwo Trans Humana, Białystok 2001.

Popławska A., W drodze ku pełnej podmiotowości. Kompetencje podmiotowe gimnazjalistów, Wydawnictwo NWSP, Białystok 2013.

Radziewicz J., Szkoła demokracji - demokracja w szkole, [w:] J. Radziewicz (red.), Nauka demokracji, CODN, Warszawa 1993.

Reforma systemu edukacji. Projekt, WSiP, Warszawa 1998.

Rozporządzenie Ministra Edukacji Narodowej z dnia 8 czerwca 2009 roku w sprawie dopuszczania do użytku w szkole programów wychowania przedszkolnego i programów nauczania oraz dopuszczania do użytku szkolnego podręczników, Dz.U. 2009, nr 89 poz. 730 .

Ryan R.M., Deci E.L., Self-Determination Theory and the Facilitation of Intrinsic Motivation, Social Development, and Well-Being, „American Psychologist" 2000, t. 55, nr 1.

Smołalski A., Koncepcja szkoły samorządnej i samoregulującej się, „Edukacja" 1987, nr 1. 
Sośnicki K., Teoria środków wychowania, Warszawa 1973, cyt. za B. Śliwerski, hasło: Autonomia, [w:] K. Chałas, A. Maj (red.), Encyklopedia aksjologii pedagogicznej, Radom 2016.

Szymański M.J., W poszukiwaniu drogi: szanse $i$ problemy edukacji $w$ Polsce, Wydawnictwo Naukowe Akademii Pedagogicznej, Kraków 2008.

Szymański M.J., Szkoła - między tradycją, dążeniem do nowoczesności i chaosem, [w:] M.J. Szymański, B. Walasek-Jarosz, Z. Zbróg (red.), Zrozumieć szkołę. Konteksty zmiany, Wydawnictwo Akademii Pedagogiki Specjalnej, Warszawa 2016.

Śliwerski B., hasło: Autonomia, [w:] K. Chałas, A. Maj (red.), Encyklopedia aksjologii pedagogicznej, Polskie Wydawnictwo Encyklopedyczne, Radom 2016.

Śliwerski B., Lęk wobec nauczycielskiej wolności, [w:] W. Prokopiuk (red.), Rozwój nauczyciela w okresie transformacji, Wydawnictwo Trans Humana, Białystok 1998.

Śliwerski B., Diagnoza uspołecznienia publicznego szkolnictwa III RP w gorsecie centralizmu, Oficyna Wydawnicza „Impuls”, Kraków 2013.

Wilczyńska W., Analiza transakcyjna a rozwijanie autonomii w komunikacji szkolnej i obcojezycznej, [w:] M. Pawlak (red.), Autonomia w nauce języka obcego - co osiągnęliśmy i dokąd zmierzamy, Wydział Pedagogiczno-Artystyczny UAM w Kaliszu, Uniwersytet Adama Mickiewicza w Poznaniu, Poznań - Kalisz - Konin 2008.

Wykorzystanie eksperymentów i metod aktywizujacych w nauczaniu problemy i wyzwania. Raport z badań, Centrum Nauki Kopernik, Warszawa 2009.

Wysocka M., Granice autonomii nauczyciela języków obcych i jego uczniów, [w:] M. Pawlak (red.), Autonomia w nauce języka obcego - co osiągnęliśmy i dokąd zmierzamy, Wydział Pedagogiczno-Artystyczny UAM w Kaliszu, Uniwersytet Adama Mickiewicza w Poznaniu, Poznań - Kalisz - Konin 2008.

\section{Netografia}

Dryden J., Internet Encyclopedia of Philosophy. A Peer-Reviewed Academic Resource, http://www.iep.utm.edu/autonomy/ (dostęp: 09.09.2019).

Maxwell B., To what extent do teachers have professional autonomy? https://www.academia.edu/12891872/To_what_extent_do_teachers_ have_professional_autonomy (dostęp: 09.09.2019). 
Polska szkoła w dobie cyfryzacji. Diagnoza 2017. Raport opracowany przez zespół badawczy Wydziału Pedagogicznego Uniwersytetu Warszawskiego oraz PCG Edukacja, Warszawa 2017. https://www. nck.pl/upload/attachments/319726/RAPORT\%20CYFRYZCJA\%20 SZK\%C3\%93\%C5\%81\%202017.pdf (dostęp: 09.09.2019). 